\title{
Evaluating Levels of Project Planning and their Effects on Performance in the Nigerian Construction Industry
}

\author{
Godwin Idoro (Department of Building, University of Lagos, Lagos, Nigeria)
}

\begin{abstract}
This study compares the level of project planning on public and private sectors projects and its impact on performance. The purpose is to create awareness of the level and effectiveness of the planning done by public and private clients in the delivery of construction projects. A questionnaire survey administered to a sample of 130 client representatives selected by stratified random sampling from the population of public and private clients in the Nigerian construction industry is used and analysed using descriptive statistics, the t-test and Spearman correlation test. The results show that the level of preconstruction planning on private sector projects is higher than that of public sector projects while the level of contract planning done by the latter is higher than that of the former. Furthermore, the performance of private sector projects is higher than that of public sector projects in many of the parameters used. However, the level of preparation of life-cycle charts that concern project delivery time in both public and private sectors projects is low and the level of project planning in the two categories of projects has a limited impact on project performance. The understanding of how public and private sectors projects perform in planning and its impact are expected to assist public and private clients to know the challenges ahead of them in their effort to improve the planning and performance of their projects.
\end{abstract}

Keywords: project performance, project planning, client type, construction industry, Nigeria.

\section{INTRODUCTION}

Projects generally can be categorised using several criteria. The most significant classification is based on the promoters or financiers of the projects who are commonly regarded as clients. Governments and their agencies as well as private bodies and individuals are the main promoters of project development in every economy. Like participants in every other sector, these promoters are categorised into two sectors namely: public and private clients.

In Nigeria, Nubi (2001) observed that governments and their agencies presently form the main clients of projects in the construction industry because they control the economy and consequently its natural resources. Private clients, on the other hand, build mainly for economic reasons or to satisfy some specific needs. He added that private clients usually are more judicious in selecting their contractors and in locating and financing their projects. The dominance of governments and their agencies over project development in Nigeria is borne out of the fact that the entire Nigerian economy including the activities of the private sector is virtually controlled by the resources generated by governments, mainly from crude oil. The dependence of the economy on government revenue is so glaring that any decrease in government earnings from crude oil any year usually result in a recession in the economy. Governments and their agencies are key players in the construction industry in Nigeria because of their economic control. Government expenditure on capital projects such as schools, hospitals, roads, housing, electricity, water supply and sporting facilities to mention a few is enormous (Okun, 2009). The Federal Government's Appropriation Acts from January 2001 to December 2008 show that the sum of N5.036 trillion, representing $43.5 \%$ of Federal Government of Nigeria (FGN) total expenditure, was earmarked for capital works while the sum of N6.545 trillion, represented $56.5 \%$ of FGN total expenditure, was earmarked for recurrent works (Federal Government of Nigeria, 2009). There are no statistical records of the contribution of the private sector to project delivery. However, what cannot be disputed is the fact that the contribution of the private sector is small when compared with that of the public sector.

The need for planning in project development and delivery is crucial because of the complex nature of resources, processes, activities and parties that are involved. Naoum et al. (2004) describe planning as one of the key tools that stakeholders use to ensure that construction projects are successful. The primary measure of construction planning effectiveness in a study conducted by Faniran et al. (1994) is the ability of a construction firm to achieve its clients' time, cost and quality objectives. In another study, Faniran et al. (1998) maintain that in construction projects the objective of planning is the completion of a prescribed amount of work within a fixed time, at a previously estimated cost and to specified standards of quality. Project plans are derived from and prepared to achieve project objectives. Although project objectives are not limited to project delivery time, cost and quality, since these are the primary objectives of a project and also the primary measures of project performance, the assertions by Faniran et al. $(1994,1998)$ are correct. In other words, the measures of the effectiveness of project planning and the measures of the performance of the project itself are the same. Therefore the planning of a successful project can be regarded as effective while that of a failed project can be described as ineffective.

Project planning is a process that is continuous throughout the delivery of a project. For this reason, project planning can be classified according to project delivery stage. Faniran et al. (1998) classify project planning into preconstruction and construction planning. These two categories of planning can otherwise be referred to as pre-contract and contract planning. Based on project stages, project planning can again be classified into conception, design, tendering and construction planning and even planning to close the delivery of a project. These various stages are carried out by professionals or parties (in-house or outsourced) engaged and paid by clients. The level of planning done in the development and delivery of a project will to a considerable extent depend on the professionals involved. Variation in the level of project planning between public and private sector projects will therefore be as a result of differences in the professionals engaged or project plans prepared during project delivery. This understanding prompts the evaluation of the levels of project planning in public and private sector projects and its impact on project performance. The study specifically evaluates the levels of use of important project delivery plans, the levels of project stage planning and their impact on the 
performance of projects procured by public and private clients in the Nigerian construction industry.

\section{AIM AND OBJECTIVES}

The aim of the study is to inform public and private clients on the level and effectiveness of the planning that is done during the procurement of construction projects. The objectives are to compare the levels of use of important project plans, the levels of project stage and overall project planning, and the performance of projects procured by public and private clients in Nigeria and the correlation between the level of planning of such projects and their performance. The achievement of these objectives will assist the two categories of clients in re-appraising their project planning efforts and strategies with a view to improving them and thereby improving the performance of their projects.

\section{HYPOTHESES}

In the attempt to achieve the above objectives, three hypotheses are postulated. The first hypothesis states that the levels of project stage planning by public and private clients in Nigeria are not significantly different. The result of the hypothesis will assist organisations, particularly government, to compare their planning efforts with those of the private sector and understand the basis of their performance in project delivery. The second hypothesis states that the performance of projects procured by public and private clients in Nigeria are not significantly different. The result of the hypothesis will assist the two categories of clients in comparing their performances in construction project delivery and evaluate the impact of their planning efforts. The third hypothesis states that the level of project planning and the performance of projects procured by public and private clients in Nigeria have no significant correlation. The result of this hypothesis is expected to be a basis for the two categories of clients to evaluate the influence of their planning efforts on the success of the projects they procure.

\section{VARIABLES}

The variables used in the study are classified into three categories, namely: projects, project planning and project performance. The projects used in the study are classified into two groups, namely: public and private sectors. Public sector projects refer to construction projects procured by public clients (i.e. governments and their agencies). Private sector projects refer to construction projects procured by private clients or organisations in Nigeria.

Planning is all about the preparation of plans, and the various plans prepared in the process of project development are essentially reports of expectation. For this reason, fourteen of the most important project plans were selected as indicators of project planning in this study. The plans were classified into three project delivery stages, namely: conception, design and construction. The plans in the project conception stage are project briefs, feasibility and viability studies and project life-cycle charts. The plans selected in the project design stage are architectural, structural, electrical and mechanical drawings, bill of quantities and project specifications. The plans selected in contract stage are programmes of work, material, labour and plant schedules and cash-flow charts. The tendering stage, which is undeniably an important project stage, was not included because as Faniran et al. (1998) observe, planning is often not carried out during the tendering process due to insufficient time and low rates of bid success.

The parameters selected as indicators of project performance are classified into two categories, namely: subjective and objective project performance indicators. Three parameters comprising clients' assessment of project duration, cost and quality used in the study are subjective project performance indicators. Four parameters comprising project time-overrun, project costoverrun, percentage of time-overrun to initial contract period and percentage of cost-overrun to initial contract sum are used as objective project performance indicators.

The investigation carried out in this study is based on the relationship between the variables selected. The planning efforts for either public or private projects can be determined by the variables of project planning and the impact of these efforts are reflected in project performance, thus indicating that a relationship exists between the variables of projects, project planning and project performance. The relationship which is evaluated here is expressed by the framework shown in Figure 1.

\section{PREVIOUS STUDIES}

Many researchers consider project planning as one of the components of project delivery process and use project performance as the basis of evaluating its effectiveness (Naoum, 1991; Ling and Chan, 2002; Thomas et al., 2002). Naoum et al. (2004) identified project planning as one of the key tools that stakeholders use to ensure that construction projects are successful. Hore et al. (1977) and Faniran et al. (2000) in separate studies described project planning as the systematic arrangement of project resources in the best way so as to achieve project objectives. Although, project planning cannot be limited to the arrangement of project resources, it is concerned mainly with the achievement of project objectives. Project success is measured in terms of the achievement of project objectives, therefore the descriptions of project planning by Hore et al. (1977), Faniran et al. (2000) and Naoum et al. (2004) can be regarded as the same.

In project delivery, project objectives are the focal point of every effort and activity. Project objectives are important in planning

Figure 1: Framework for comparing the level of project planning in public and private projects and its impact on their projects

\begin{tabular}{|c|c|c|}
\hline & Project planning & Proiect performance \\
\hline $\begin{array}{l}\text { Projects } \\
\text { 1. Public } \\
\text { 2. Private }\end{array}$ & $\begin{array}{l}\text { 1. Project plans } \\
\text { 2. Project conception } \\
\text { 3. Project design } \\
\text { 4. Contract } \\
\text { 5. Overall }\end{array}$ & $\begin{array}{l}\text { 1. Time overrun } \\
\text { 2. Cost overrun } \\
\text { 3. \% time-overrun/initial contract period } \\
\text { 4. \% cost-overrun/initial contract sum }\end{array}$ \\
\hline
\end{tabular}


because project plans are derived from them. In project planning, project objectives are first defined; thereafter the strategies to achieve them are formulated and presented as project plans and these are used in evaluating the achievement of the objectives. Project planning can therefore be regarded as the process of defining project objectives, determining the framework, methods, strategies, tactics, targets and deadlines to achieve the objectives and the techniques of communicating them to project stakeholders. The process of project planning requires that clients' expectations and available resources be defined first, matched to set project objectives, so that available options are identified and evaluated and the most appropriate frameworks, strategies and tactics to achieve the objectives are selected. It ends with communicating the objectives and the frameworks, methods, strategies, targets/ deadlines to achieve them to people, parties and organisations concerned with their implementation, monitoring and control. The end products of project planning are numerous project plans that represent defined strategies to achieve defined project objectives.

These plans communicate both project objectives and the strategies for achieving them, and they are the basis for determining the achievement of project objectives that otherwise refer to the success of a project. While planning is a process that requires effort, plans are the results of the process and the efforts put in. Planning that does not produce a plan can therefore be regarded as an effort without result. Planning efforts can be in the form of design, tendering and programming and the results are design documents, tender plans, charts, schedules and programmes of resources and works to be carried out. Each of the plans serve a specific purpose that has to do with achievement of specific project objectives. For this reason, project sponsors are often encouraged to ensure that many of these plans are prepared during project development by engaging professionals who are qualified to prepare them.

However, while the preparation of these plans is expected to enhance the success of a project, it may also prolong its delivery time. Sommerville et al. (2004) described the documentation of information which invariably refers to planning as a key enabler to the running of any project, and identified inadequate documentation as one of the causes of conflicts. Pheng and Ting (1998) remarked that while every effort has to be made to ensure that all aspects of the design are discussed and reviewed, the time spent on the development of design should not be too long to the extent of affecting the overall construction time and the achievement of the client's desired financial objectives. In a study of factors influencing design development time of commercial properties in Singapore, the researchers discovered that the larger the design team, the longer it takes to complete design development. The preceding stage of project implementation or production involves the implementation of the plans prepared. The effectiveness of the plans is measured by project success. The preparation of project plans is used in this study for the measurement of the level of project planning.

Faniran et al. (1998) described project planning as the process of determining appropriate strategies for the achievement of predefined project objectives. They classified project planning into preconstruction and construction planning. Preconstruction planning is regarded as pre-contract planning which refers to the planning done during the conception, design and tendering stages of a project while construction planning often refers to contract planning which describes the planning done during the construction of a project. In another classification of project planning, Dvir et al. (2003) identified three levels of project planning, namely: the end-user level where planning focuses mainly on the functional characteristics of the project end-product, the technical level that focuses on the technical specifications of the project deliverables that are needed to support the functional requirements, and the project management level that focuses on planning the activities and processes that need to be carried out to ensure that the technical work proceed effectively. These three levels of planning can otherwise be regarded as project conception planning, project design planning and contract planning. What is understood from the review above is that different forms of planning are carried out in each of the five stages namely: conception, design, tendering, construction and closeout (Puthamont and Charoenngam, 2004) in a project and project planning can be categorised by the stage at which it is done.

Project performance remains a prominent issue in project delivery all over the world. This is so because projects involve defined objectives which must be achieved and numerous resources which need to be efficiently utilised. The need for participants involved in construction project delivery to develop and use tools for performance measurement was emphasised in the UK and Sweden (Robinson et al. 2005). Several researchers also developed numerous parameters for measuring project performance (Naoum, 1999; Ling and Chan, 2002; Thomas et al., 2002; Josephson and Lindstrom, 2007). In a review of the parameters used for measuring project performance in 16 journal papers, Josephson and Lindstrom (2007) identify 250 parameters. From the review of previous research studies on project performance parameters, Ling (2004) identified and evaluated 70 potential factors for measuring project performance.

These and other parameters that have been used in research studies can be classified into two broad categories, namely: subjective and objective parameters. Ling (2004) states that the performance of a project is multifaceted and may include unit cost, construction and delivery speeds and the level of client satisfaction. Pinto and Slevin (1998) classify project performance parameters into (1) internal factors that are project variables, namely: schedule, cost and quality, and (2) external factors that are concerned with stakeholder satisfaction of the performance of a project and the perceived impact on an organisation's effectiveness. Ling et al. (2004) identified two categories of indicators of project success, namely: product success that consists of measures of achievement of quality standards, and process success that is made up of variables that measure the achievement of time and cost. Subjective parameters refer to stakeholder satisfaction with the end-product (i.e. the completed structure) while objective parameters refer to project variables such as schedule, cost and quality that are used for setting and defining project objectives and for setting targets and deadlines for project delivery. The importance of the classification of the parameters of project performance is that although all the available parameters cannot be used each time performance is measured, any measurement that does not include parameters from the two categories may not be reliable. The fact that stakeholders spent more time and money than proposed for a project may not decrease their satisfaction with the performance of the project.

Stakeholder satisfaction has become prominent in modern approaches to performance measurement. Kotler (2000) maintained that satisfaction can be understood as a person's feeling resulting from the performance of a product as compared to the person's expectation. Project stakeholders refer to individuals and organisations that are actively involved in a project or whose interest may be positively or negatively affected as a result of project execution (Project Management Institute, 2004). Marjolein et al. (2008) maintained that in project management, it is commonly accepted that the interest of stakeholders need to be dealt with to support the success of a project. Project Management 
Institute (2004) stated that the project team must identify the stakeholders, determine their requirements and expectations, and to the extent possible, manage their influence in relation to the requirements to ensure a successful project.

The stakeholders of a construction project are many and they include the project sponsors such as the client, developer and financier, the project team members and the customers. Faniran et al. (1994) and Neto et al. (2007) regarded the client as the most important stakeholder in construction project delivery. Faniran et al. (1994) considered the success of a contractor as his ability to achieve its clients' time, cost and quality objectives while Neto et al. (2007) believed that matching or exceeding clients' expectations results in satisfied clients. They added that this can reflect on how loyal a client becomes to a provider or a brand and can result in higher sales volumes, lower levels of sensitivity to price and generation of positive comments about the provider and the brand. Since client requirements are the focus of a project and project objectives are defined from them, it means that project success is all about achieving client requirements and satisfaction.

Client satisfaction can be measured from several perspectives (Idoro, 2008), however three parameters (time, cost and quality) have remained the most prominent in research studies. Josephson and Lindstrom (2007) maintained that project goals that consider client goals are measured from several perspectives, but the main aim is to stimulate clients to identify and clearly present their goals and to stimulate all managers involved to inform and remind all individuals of the goals. Hatush and Skitmore (1997) stated that success in a project is generally operationalised into time, cost and quality. Michell et al. (2007) remarked that the primary concern of construction clients is that their projects are completed within budget, on time and to the required level of quality. On the basis of the above assertions, this study selected the three parameters of project time, cost and quality as the primary concern of clients and as the variables for measuring client satisfaction.

Objective parameters of project performance are usually derived from the parameters used for defining project objectives and setting targets and deadlines for the delivery of a project. The same parameters are used for the monitoring, evaluation and control of a project. Although these parameters are many, two of them, namely schedule and cost, are common with research studies. The reasons for this are not farfetched. Michell et al. (2007) stated that timely completion of a construction project is frequently seen as a major criterion of project success by clients, contractors and consultants alike. They also added that costoverruns are identified by them as one of the principal factors leading to the high cost of construction. The third parameter (quality) is not a common objective parameter in research studies because as Vincent and Joel (1995) opined, stakeholders see the goal of quality management as customer satisfaction. From the perspective of previous studies, two parameters, namely timeoverrun and cost-overrun, remain the prominent indicators of objective measurement of project performance. However, these two parameters have their limitation because their values depend to a great extent on the initial period and budget for a project.

This study selects four parameters, namely time-overrun, costoverrun, percentage of time-overrun to initial contract period and percentage of cost-overrun to initial contract sum, as the variables for objective measurement of project performance. The factors of time and cost-overruns to initial contract period and durations were selected based on the understanding that the initial contract period and sum have significant influence on project time-overrun and cost-overrun.

\section{RESEARCH METHODS}

A field survey approach was adopted because primary data were required and the population of the study was large. The population consisted of public and private clients in the Nigerian construction industry. Public clients were made up of federal, state and local governments and their agencies. Private clients were mainly corporate organisations in the banking, oil and gas and manufacturing industries. A preliminary survey was first conducted because there was no reliable statistics of private clients in Nigeria. In the preliminary survey, recently completed construction projects were identified and the list of their owners or clients was compiled. From the preliminary survey, 232 public and private clients were identified and used as the population frame for the study. A major project procured by each of the clients that was identified during the preliminary survey was selected for the study.

The research instrument used for the study was a structured questionnaire. The instrument was administered on the population frame and 130 of the respondents made up of 92 public clients and 38 private clients were selected by stratified random sampling to form the study sample. The respondents were project leaders such as project managers and architects who were representatives of the clients selected. The end products of project planning are numerous plans, therefore data were collected on 14 project plans that represented different forms of planning. The plans were selected from three project stages of conception, design and contract. Respondents were requested to indicate whether each of the plans was prepared or not prepared during the delivery of the projects selected. Their responses were weighted as follows: prepared $=1$; not prepared $=0$. Data collected on objective parameters of project performance were initial except for final contract periods and sums. Subjective parameters of project performance were measured on a scale of 1-3 which represented low-high.

The level of use (LOP) of project plans was determined by a ratio as explained below, while the level of project stage planning was determined by mean. Their ranks were used to compare the levels of use of the selected project plans, project stage planning, overall project planning and the performance of projects procured by public and private clients. To evaluate whether the differences in the levels of stage and overall project planning between public and private sector projects were significant or not, the t-test (a tool for testing difference between two variables) was used. To evaluate the influence of project stage and overall project planning on the performance of public and private sector projects, the Spearman correlation test (a tool for the test of relationship between two variables) was considered most suitable and adopted.

\section{RESULTS}

\section{LEVELS OF USE OF SELECTED PROJECT PLANS IN PUBLIC AND PRIVATE SECTOR PROJECTS}

One of the objectives of this study is to compare the levels of project planning done by public and private clients during the delivery of construction projects in Nigeria. For this purpose, selected project plans were used to represent project planning. Fourteen project plans that represented different forms of project planning were selected from the three project stages of conception, design and contract.

Respondents were requested to indicate the plans prepared for the projects selected using 'yes' to represent prepared and 'no' for not prepared. The ratio of the number of projects in which a plan is prepared to the number of projects that their project leaders 
responded to data requested was derived to represent the LOP score. The ranking of these scores was analysed. The results are presented in Table 1.

The results on project conception planning in revealed that project brief ranks first in level of use in both public $(\mathrm{LOP}=0.94)$ and private $(\mathrm{LOP}=0.88)$ projects. Feasibility and viability study report ranks second in both public $(\mathrm{LOP}=0.76)$ and private $(\mathrm{LOP}=0.84)$ sector projects while project life-cycle chart $\left(\mathrm{LOP}_{\text {public }}=0.49\right.$; $\mathrm{LOP}_{\text {private }}=0.67$ ) ranks last (third) in the two categories of projects These results imply that the ranking of the levels of use of the three project plans is the same in both public and private sectors' projects. This is an indication that the priority attached to the three project conception plans is the same among the two categories of clients.

The results on project design planning in revealed that, in public sector projects, bill of quantities $(\mathrm{LOP}=0.94)$ and project specifications $(\mathrm{LOP}=0.94)$ rank first in level of use. Structural drawings $(\mathrm{LOP}=0.78)$ ranks third, architectural $(\mathrm{LOP}=0.77)$ and electrical $(L O P=0.72)$ drawings rank fourth and fifth respectively while mechanical drawings $(\mathrm{LOP}=0.64)$ ranks last in level of use. In private sector projects, structural drawings $(\mathrm{LOP}=1.00)$ ranks first in level of use. Architectural drawings ( $\mathrm{LOP}=0.97)$, electrical drawings ( $\mathrm{LOP}=0.97)$ and mechanical drawings $(\mathrm{LOP}=0.97)$ rank second while bill of quantities $(\mathrm{LOP}=0.94)$ and project specifications ( $\mathrm{LOP}=0.82$ ) rank fifth and sixth respectively. The results indicate that the ranking and by implication, the priority accorded project plans that are prepared at the design stage of project development by public and private clients, are not the same. While public clients give more priority to bill of quantities and specifications than project drawings, the reverse is the case with private clients.

The results on contract planning revealed that, in public sector projects, programme of work $(\mathrm{LOP}=0.91)$ ranks first in level of use. Material schedule $(\mathrm{LOP}=0.78)$, labour schedule $(\mathrm{LOP}=0.69)$ plant schedule $(\mathrm{LOP}=0.62)$ and cash-flow chart $(\mathrm{LOP}=0.54)$ rank second, third, fourth and fifth respectively. In private sector projects, programme of work ( $\mathrm{LOP}=0.86$ ) ranks first in level of use. Material schedule $(\mathrm{LOP}=0.59)$ and cash-flow chart $(\mathrm{LOP}=0.59)$ rank second while labour schedule $(\mathrm{LOP}=0.47)$ and plant schedule $(\mathrm{LOP}=0.30)$ rank fourth and fifth respectively in level of use. These results reveal that there is a slight variation in the priorities accorded the selected contract plans by the two categories of clients. The difference lies in the priority accorded cash-flow charts by the two clients. While private clients accord it second priority, governments and their agencies consider it last.

\section{COMPARING THE LEVELS OF USE OF SELECTED PROJECT PLANS IN PUBLIC AND PRIVATE SECTOR PROJECTS}

Another research objective of this study is to compare the level of use of each project plan in public and private sector projects. Such a comparison will assist stakeholders to compare the level of project planning done by the two categories of clients and to relate the performance of projects procured by them to their level of project planning. For the purpose of this comparison, the levels of use of each of the selected project plans in public and private sector projects derived above were ranked. The results are also included in Table 1 using underlined LOP scores to highlight the higher rank.

The results revealed that, in project conception planning, the level of use of project brief by public clients $(\mathrm{LOP}=0.94)$ ranks first while that of private clients $(\mathrm{LOP}=0.88)$ ranks second. However, the levels of use of feasibility and viability studies $(\mathrm{LOP}=0.84)$ and project life-cycle chart $(\mathrm{LOP}=0.67)$ by private clients rank first while the levels of use of feasibility and viability studies $(L O P=0.76)$ and project life-cycle charts $(\mathrm{LOP}=0.49)$ by public clients rank second. These results indicate that governments and their agencies do more briefing and prepare more statements of project brief than private organisations. However, private organisations use feasibility and viability studies and project life-cycle charts more than governments and their agencies.

In project design planning, the levels of use of bill of quantities (LOP $=0.94)$ by both public and private clients ranked the same. The level of use of project specifications $(\mathrm{LOP}=0.94)$ by governments and their agencies ranks first while that of private organisations ( $L O P=0.82)$ ranks second. However, the levels of use of structural ( $L O P=1.00)$, architectural $(\mathrm{LOP}=0.97)$, electrical $(\mathrm{LOP}=0.97)$ and mechanical $(\mathrm{LOP}=0.97)$ drawings by private clients rank first while the levels of use of structural ( $L O P=0.78)$, architectural $(\mathrm{LOP}=0.77)$, electrical $(\mathrm{LOP}=0.72)$ and mechanical $(\mathrm{LOP}=0.64)$ drawings by governments and their agencies rank second. These results indicate that the level of use of bill of quantities for construction project delivery by public and private

Table 1: Ranking of the levels of use of selected project plans in public and private sector projects in Nigeria

\begin{tabular}{|c|c|c|c|c|c|c|c|c|c|c|}
\hline \multirow[t]{2}{*}{ Project plans } & \multicolumn{5}{|c|}{ Public sector projects } & \multicolumn{5}{|c|}{ Private sector projects } \\
\hline & $\mathrm{N}$ & Yes & No & LOP & Rank & $\mathrm{N}$ & Yes & No & LOP & Rank \\
\hline \multicolumn{11}{|l|}{$\begin{array}{l}\text { Project conception } \\
\text { planning }\end{array}$} \\
\hline Project brief & 84 & 79 & 5 & $\underline{0.94}$ & 1 & 33 & 29 & 4 & 0.88 & 1 \\
\hline Feasibility \& viability study & 79 & 60 & 19 & 0.76 & 2 & 32 & 27 & 5 & $\underline{0.84}$ & 2 \\
\hline $\begin{array}{l}\text { Project life-cycle chart } \\
\text { Project design }\end{array}$ & 76 & 37 & 39 & 0.49 & 3 & 27 & 18 & 9 & $\underline{0.67}$ & 3 \\
\hline Bill of quantities & 85 & 80 & 5 & $\underline{0.94}$ & 1 & 36 & 34 & 2 & $\underline{0.94}$ & 5 \\
\hline Project specifications & 80 & 75 & 4 & 0.94 & 1 & 34 & 28 & 6 & 0.82 & 6 \\
\hline Structural drawings & 78 & 61 & 17 & 0.78 & 3 & 37 & 37 & 0 & 1.00 & 1 \\
\hline Architectural drawings & 82 & 63 & 19 & 0.77 & 4 & 36 & 35 & 1 & $\overline{0.97}$ & 2 \\
\hline Electrical drawings & 75 & 54 & 21 & 0.72 & 5 & 34 & 33 & 1 & $\overline{0.97}$ & 2 \\
\hline Mechanical drawings & 74 & 47 & 27 & 0.64 & 6 & 34 & 33 & 1 & 0.97 & 2 \\
\hline \multicolumn{11}{|l|}{ Contract planning } \\
\hline Programme of work & 86 & 78 & 8 & $\underline{0.91}$ & 1 & 36 & 31 & 5 & 0.86 & 1 \\
\hline Material schedule & 81 & 63 & 18 & $\underline{0.78}$ & 2 & 34 & 20 & 14 & 0.59 & 2 \\
\hline Labour schedule & 78 & 54 & 24 & $\underline{0.69}$ & 3 & 30 & 14 & 16 & 0.47 & 4 \\
\hline Plant schedule & 76 & 47 & 29 & 0.62 & 4 & 27 & 8 & 19 & 0.30 & 5 \\
\hline Cash-flow chart & 70 & 36 & 34 & 0.54 & 5 & 27 & 16 & 11 & 0.59 & 2 \\
\hline
\end{tabular}


clients is the same. However, governments and their agencies use project specifications more than private organisations while the latter prepares project drawings (architectural, structural, electrical and mechanical) more than the former during project delivery. In contract planning, governments and their agencies prepare programme of work, material, labour and plant schedules more than private organisations but the latter prepare cash-flow charts more than the former during project delivery.

\section{COMPARING THE LEVEL OF PROJECT STAGE PLANNING IN PUBLIC AND PRIVATE SECTOR PROJECTS}

The results in Table 1 have shown that the levels of use of the selected plans by public and private clients differ from one plan to another. These results indicate that the levels of project planning by the two types of client also differ. As a background to the understanding of the impact of project planning on the performance of projects procured by the two clients, this study evaluates the levels of planning done by the two categories of clients at major project stages. Three project stages (conception, design and contract) and overall project planning were selected for evaluation. The level of project stage planning was measured by the number of plans prepared in each project used in the study to the total number of selected plans in each stage. The level of overall project planning was measured as the number of conception, design and contract plans prepared in each project to the total selected plans in the three project stages. The ranking of the levels of project stage planning and overall project planning done by the two categories of clients was thereafter determined. The results are presented in Table 2 .

The results show that the level of conception planning done by private clients $(\bar{x}=0.705)$ ranks first while that of public clients $(\bar{x}=0.679)$ ranks second. The results show that private clients do more planning at the conception stage of construction project delivery than governments and their agencies. The results also show that the level of design planning done by private clients $(\bar{x}=0.896)$ ranks first while that of public clients $(\bar{x}=0.734)$ ranks second. The results equally imply that private organisations do more planning at the design stage of construction project delivery than governments and their agencies. However, the results relative to contract planning show that the level of contract planning done by public clients $(\bar{x}=0.632)$ ranks first while that of private clients $(\bar{x}=0.470)$ ranks second. This result shows that governments and their agencies do more planning at the contract stage than private organisations. The results in Table 2 also show that the level of overall project planning $(\bar{x}=0.699)$ done by private clients ranks first while that of public clients $(\bar{x}=0.670)$ ranks second. The results show that private clients do more overall planning during construction project delivery than governments and their agencies.
DIFFERENCE IN THE LEVEL OF PROJECT STAGE PLANNING BETWEEN PUBLIC AND PRIVATE SECTOR PROJECTS

The previous results show that private clients do more conception and design planning than public clients whereas the latter do more contract planning than the former during project delivery. The study proceeded to determine whether or not these differences are significant. This investigation involves the test of the first research hypothesis of the study which states that the levels of project planning done by public and private clients are not significantly different. The level of project planning was measured as explained above. The hypothesis was tested using a t-test with $p \leq 0.05$. The rule for the acceptance or rejection of the hypothesis is that if the $p$-value $>0.05$, the hypothesis is accepted but if the $p$-value $\leq 0.05$, the hypothesis is rejected. The results of the test are presented in Table 3 .

The results of the test of difference in the levels of conception and overall planning done by public and private clients revealed that the t-values for difference in conception planning $(-0.449)$ and overall project planning $(-0.655)$ are very low and their respective $p$-values (0.654) and (0.514) are greater than the critical p-value (0.05). Therefore, the hypothesis is accepted. The result implies that the difference in the levels of conception and overall project planning done by public and private clients is insignificant. The results also revealed that the t-values for difference in design planning (-3.020) and contract planning (2.443) between the two clients are high and their respective $p$-values (0.003) and (0.016) are less than the critical $p$-value (0.05). Therefore, the hypothesis is rejected. The result implies that the difference in the levels of design and contract planning done by public and private clients is significant. These results confirm that more planning is done at the design stage in projects procured by private clients than in projects procured by public clients whereas more planning is done at the contract stage in projects procured by public clients than in projects procured by private clients.

\section{COMPARING THE PERFORMANCE OF PROJECTS PROCURED BY PUBLIC AND PRIVATE CLIENTS}

In the attempt to evaluate the impact of the levels of project planning by the two categories of clients, this study investigated the performance of projects procured by them. For this purpose, three indicators of subjective project performance (client satisfaction with project duration, cost and quality) and four indicators of objective project performance (project time and cost overruns, percentages of time-overrun to initial contract period and cost-overrun to initial contract sum) were selected. Subjective project performance indicators were measured using three ranks, namely low, moderate and high. The ranks were scored as follows: low $=1$, moderate $=2$ and high $=3$. Initial and actual
Table 2: Ranking analysis by planning stage

\begin{tabular}{llllll}
\hline Planning stage & Sector & $\mathrm{N}$ & Mean & Std. dev. & Rank \\
\hline Conception & Private & 36 & 0.705 & 0.3114 & 1 \\
& Public & 86 & 0.679 & 0.2782 & 2 \\
Design & Private & 37 & 0.896 & 0.1809 & 1 \\
& Public & 86 & 0.734 & 0.3030 & 2 \\
Contract & & & & & \\
& Public & 88 & 0.632 & 0.3456 & 1 \\
Overall & Private & 37 & 0.470 & 0.3170 & 2 \\
& & & & & \\
& Private & 37 & 0.699 & 0.1881 & 1 \\
\hline
\end{tabular}

$\mathrm{N}=$ Number of respondents that supplied data

Std. dev.=Standard deviation
Table 3: Results of t-test for differences in the levels of project planning

\begin{tabular}{lllllll}
\hline Planning stage & Sector & $\mathrm{N}$ & $\mathrm{t}$-value & $\mathrm{Df}$ & $\mathrm{p}$-value & Decision \\
\hline Conception & $\begin{array}{l}\text { Private } \\
\text { Public }\end{array}$ & 36 & -0.449 & 119 & 0.654 & Accept \\
& & & & & \\
Design & $\begin{array}{l}\text { Private } \\
\text { Public }\end{array}$ & 36 & -3.020 & 121 & 0.003 & Reject \\
& Public & 88 & 2.443 & 123 & 0.016 & Reject \\
Contract & Private & 37 & & & & \\
& Private & 37 & -0.655 & 124 & 0.514 & Accept \\
Overall & Public & 89 & & & & \\
\hline
\end{tabular}

$\mathrm{N}=$ Number of respondents that supplied data

$\mathrm{Df}=$ Degree of freedom 
contract periods from which project time-overrun was derived were measured in weeks while initial and final contract sums from which project cost-overrun was derived were measured in Naira (Nigerian currency). The percentage of time-overrun to initial contract period and the percentage of cost-overrun to initial contract sum were further derived from the data on contract durations and sums collected. The rankings of the performances of the projects procured by the two categories of clients are presented in Table 4.

The results revealed that private client satisfaction with project duration $(\overline{\mathrm{x}}=2.54)$, cost $(\overline{\mathrm{x}}=2.45)$ and quality $(\overline{\mathrm{x}}=2.58)$ rank first while public client satisfaction with project duration $(\bar{x}=2.21)$, cost $(\bar{x}=2.10)$ and quality $(\bar{x}=2.52)$ rank second. These results indicate that private clients are more satisfied with the performance of projects procured by them than public clients. Also, project timeoverrun $(\bar{x}=3.74$ weeks) and cost-overrun ( $\bar{x}=$ N64.88 million) recorded in projects procured by public clients rank first while the time-overrun ( $\bar{x}=3.64$ weeks) and cost-overrun ( $\bar{x}=\mathrm{N} 27.23$ million) of projects procured by private clients rank second. These results show that the time and cost-overruns on projects procured by governments and their agencies are higher than those of projects procured by private clients. The results also suggest that the performances of projects procured by private clients are better than those of projects procured by public clients.

The percentage of cost-overrun to initial contract sum $(\bar{x}=13.59)$ of projects procured by public clients ranks first while that of projects procured by private clients $(\bar{x}=10.15)$ ranks second. This result also suggests that the performance of projects procured by private clients are better than the performances of projects procured by governments and their agencies. However, the percentage of time-overrun to initial contract period $(\bar{x}=22.17)$ of projects procured by private clients ranks first while that of projects procured by public clients $(\bar{x}=35.84)$ ranks second. This result indicates that projects procured by governments and their agencies are better in terms of the percentage of time-overrun to initial contract period. Since the use of percentage of timeoverrun to initial contract period is aimed at removing the effect of initial contract period on project time-overrun, the result tends to imply that projects procured by governments and their agencies are better and shorter in terms of delivery period.

\section{DIFFERENCE IN THE PERFORMANCE OF PUBLIC AND PRIVATE SECTOR PROJECTS}

The previous results show that the performance of public sector projects rank higher than those of private sector projects in some parameters while the reverse is the case in others. Further investigation was carried out to establish whether or not these differences are significant. This investigation involves the test of the second research hypothesis of the study which states that the performances of projects procured by public and private clients in Nigeria are not significantly different. The seven parameters of project performance used for the test were measured as explained above. The hypothesis was tested using the t-test with $p \leq 0.05$. The rule for the acceptance or rejection of the hypothesis is that if the $p$-value $>0.05$, the hypothesis is accepted but if the $p$-value $\leq 0.05$, the hypothesis is rejected. The results of the test are presented in Table 5.

Table 4: Ranking analysis by performance

\begin{tabular}{lrrrrrrrr}
\hline Parameter & \multicolumn{3}{c}{ Public sector projects } & \multicolumn{4}{c}{ Private sector projects } \\
& N Mean & Std. dev. Rank & N Mean Std. dev. Rank \\
\hline Clients' satisfaction with duration & 92 & 2.21 & 0.704 & 2 & 37 & 2.54 & 0.605 & 1 \\
Clients' satisfaction with cost & 92 & 2.10 & 0.696 & 2 & 38 & 2.45 & 0.504 & 1 \\
Clients' satisfaction with quality & 92 & 2.52 & 0.671 & 2 & 38 & 2.58 & 0.599 & 1 \\
Project cost-overrun & 65 & 64.88 & 414.705 & 1 & 22 & 27.23 & 85.072 & 2 \\
Project time-overrun & 69 & 3.74 & 8.196 & 1 & 22 & 3.64 & 8.156 & 2 \\
\% time-overrun/initial contr. period & 72 & 18.35 & 35.837 & 2 & 23 & 22.17 & 42.483 & 1 \\
$\%$ cost-overrun/initial contr. sum & 59 & 13.59 & 23.961 & 1 & 20 & 10.15 & 12.266 & 2 \\
\hline N=Number of respondents that supplied data & & & & & & & &
\end{tabular}

Table 5: Results of t-test for differences in the performance of public and private sector proejects

\begin{tabular}{|c|c|c|c|c|c|c|}
\hline Parameter & Sector & $\mathrm{N}$ & t-value & Df & $p$-value & Decision \\
\hline Project duration & $\begin{array}{l}\text { Public } \\
\text { Private }\end{array}$ & $\begin{array}{l}90 \\
37\end{array}$ & -2.569 & 125 & 0.011 & Reject \\
\hline Project cost & $\begin{array}{l}\text { Public } \\
\text { Private }\end{array}$ & $\begin{array}{l}90 \\
38\end{array}$ & -2.756 & 126 & 0.007 & Reject \\
\hline Project quality & $\begin{array}{l}\text { Public } \\
\text { Private }\end{array}$ & $\begin{array}{l}90 \\
38\end{array}$ & -0.537 & 126 & 0.592 & Accept \\
\hline Time-overrun & $\begin{array}{l}\text { Public } \\
\text { Private }\end{array}$ & $\begin{array}{l}67 \\
22\end{array}$ & 0.159 & 87 & 0.874 & Accept \\
\hline Cost-overrun & $\begin{array}{l}\text { Public } \\
\text { Private }\end{array}$ & $\begin{array}{l}63 \\
22\end{array}$ & 0.493 & 83 & 0.623 & Accept \\
\hline $\begin{array}{l}\% \text { time-overrun/initial } \\
\text { contract period }\end{array}$ & $\begin{array}{l}\text { Public } \\
\text { Private }\end{array}$ & $\begin{array}{l}70 \\
23\end{array}$ & -0.356 & 91 & 0.723 & Accept \\
\hline $\begin{array}{l}\% \text { cost-overrun/initial } \\
\text { contract sum }\end{array}$ & $\begin{array}{l}\text { Public } \\
\text { Private }\end{array}$ & $\begin{array}{l}57 \\
20\end{array}$ & 0.627 & 75 & 0.532 & Accept \\
\hline
\end{tabular}


The results show that the $p$-values for the test of differences in time-overrun (0.874), cost-overrun (0.623), percentage of timeoverrun to initial contract period $(0.723)$, percentage of costoverrun to initial contract sum (0.532) and clients' assessment of project quality (0.592) between public and private sector projects are greater than the critical p-value (0.05), and therefore, the hypothesis is accepted. These results imply that the differences in the overruns in proposed duration and budget and client perception of the quality of public and private sector projects in Nigeria are insignificant. However, the $p$-values for the test of differences in clients' assessment of project duration (0.011) and cost $(0.007)$ between public and private sector projects are less than the critical p-value (0.05), and therefore, the hypothesis is rejected. The results confirm the findings in Table 4 that private clients are more satisfied with the durations and costs of projects procured by them than public clients.

\section{CORRELATION BETWEEN THE LEVEL OF PROJECT PLANNING AND THE PERFORMANCE OF PROJECTS PROCURED BY PUBLIC ORGANISATIONS}

In order to evaluate the impact of project planning on the performance of projects procured by the two categories of clients, the correlation between the levels of project stage planning and project performance was investigated. The investigation involves the test of the third hypothesis of the study, which states that the level of project planning and the performance of projects procured by public and private clients have no significant correlation. The hypothesis was tested using the Spearman correlation test with $p \leq 0.05$. The rule for the acceptance or rejection of the hypothesis is that if the $p$-value $>0.05$ the hypothesis is accepted, but if the $p$-value $\leq 0.05$ the hypothesis is rejected. The results of the test are presented in Table 6.

The results showed that the $p$-values for the test of correlation between the level of conception planning and clients' level of satisfaction with contract durations (0.028) and the time-overrun (0.018) of projects procured by public clients are less than the critical p-value (0.05). Therefore, the hypothesis is rejected. The result simply implies that the level of planning at the conception stage of construction projects procured by governments and their agencies has significant influence on clients' satisfaction with the delivery period and the time-overrun recorded in the projects. However, the $p$-values for the test of correlation between the level of conception planning and clients' level of satisfaction with contract cost $(0.717)$ and quality $(0.176)$, cost-overrun $((0.961)$, percentage of time-overrun to initial contract period $(0.090)$ and percentage of cost-overrun to initial contract sum $(0.913)$ are greater than the critical p-value (0.05). Therefore, the hypothesis is accepted. These results indicate that the level of planning unertaken by governments and their agencies at the conception stage has no significant influence on their satisfaction with project cost and quality, cost-overrun, percentage of cost-overrun to initial contract sum and the percentage of time-overrun to initial contract period.

The results also revealed that the $p$-values for the test of correlation between the level of design planning and cost-overrun $(0.013)$ and the percentage of cost-overrun to initial contract sum $(0.008)$ are less than the critical p-value $(0.05)$. Therefore, the hypothesis is rejected. The $p$-values for the test of correlation between the level of design planning and clients' satisfaction with project time (0.941), cost (0.199), quality (0.392), time-overrun $(0.937)$ and percentage of time-overrun to initial contract period $(0.942)$ are greater than the critical $p$-value $(0.05)$. Therefore, the hypothesis is accepted. These results simply imply that the level of planning at the design stage of project delivery by governments and their agencies has significant influence on the final cost of the projects procured by them. However, it does not have any influence on the quality and duration of the projects.

The $p$-value for the test of correlation between the level of contract planning and clients' satisfaction with project quality $(0.044)$ is less than the critical p-value $(0.05)$ therefore, the hypothesis is rejected. The p-values for the test of correlation between the level of contract planning and clients' satisfaction with project time (0.162) and cost (0.753), time-overrun (0.213), cost-overrun (0.076), percentage of time-overrun to initial contract period (0.412) and percentage of cost-overrun to initial contract sum $(0.258)$ are greater than the critical $p$-value $(0.05)$ therefore, the hypothesis is accepted. These results imply that the level of planning done at the contract stage of project delivery by governments and their agencies has significant influence on clients' satisfaction with project quality but it does not have any influence on the duration and cost of projects procured by them.

Furthermore, the $p$-values for the test of correlation between the level of overall project planning and clients' satisfaction with project time (0.134), cost $(0.264)$, quality $(0.088)$, time-overrun (0.562), cost-overrun (0.195), percentage of time-overrun to initial contract period $(0.277)$ and percentage of cost-overrun to initial contract sum (0.386) are greater than the critical p-value $(0.05)$. Therefore, the hypothesis is accepted. These results are notable because while the levels of planning at different stages of project delivery influence the different parameters of project performance, the level of overall planning that is the summary of the levels of planning at all the stages of project development has no influence on all the parameters of project performance. This result tends to imply that the overall planning by governments and their agencies do not have any influence on project performance.

\section{CORRELATION BETWEEN THE LEVEL OF PROJECT PLANNING AND THE PERFORMANCE OF PROJECTS PROCURED BY PRIVATE ORGANISATIONS}

The correlation between the level of project planning and the performance of projects procured by private clients was also investigated. This entailed the test of the third research hypothesis of the study. The results are presented in Table 7.

The results relative to conception planning showed that the $p$-values for the test of correlation between the level of conception planning and project time-overrun (0.001), cost-overrun (0.017), percentage of time-overrun to initial contract period $(0.006)$ and percentage of cost-overrun to initial contract sum (0.039) are less than the critical p-value (0.05). Therefore, the hypothesis is rejected. However, the p-values for the test of correlation between the level of conception planning and clients' satisfaction with project time $(0.215)$, cost $(0.986)$ and quality $(0.244)$ are greater than the critical $p$-value $(0.05)$. Therefore, the hypothesis is accepted. These results indicate that while the level of planning at the conception stage of projects procured by private clients has significant influence on the duration and cost of the projects, it does not influence the level of satisfaction of private clients with the duration, cost and quality of the projects they procure.

The $p$-value for the test of correlation between the level of project design planning and project time-overrun $(0.002)$ is less than the critical $p$-value $(0.05)$. Therefore, the hypothesis is rejected. However, the $p$-values for the test of correlation between the level of project design planning and private clients' satisfaction with project duration $(0.847)$, cost $(0.124)$ and quality $(0.407)$ and project cost-overrun (0.794), percentage of time-overrun to initial contract period $(0.461)$ and percentage of cost-overrun to initial contract sum (0.903) are greater than the critical p-value (0.05). Therefore, the hypothesis is accepted. These results indicate that 
Table 6: Results of the Spearman test of correlation between the level of project planning and performance of projects procured by public clients

\begin{tabular}{llllll}
\hline Parameter & & Conception & Design & Contract & Overall \\
\hline Clients' satisfaction with duration & $\mathrm{N}$ & 88 & 88 & 90 & 91 \\
& $\mathrm{R}$ & 0.234 & 0.008 & 0.149 & 0.158 \\
& $\mathrm{p}$-value & 0.028 & 0.941 & 0.162 & 0.134 \\
& $\mathrm{~N}$ & 88 & & & \\
Clients' satisfaction with cost & $\mathrm{R}$ & 0.039 & 0.138 & 0.034 & 0.118 \\
& $\mathrm{p}$-value & 0.717 & 0.199 & 0.753 & 0.264 \\
& & & & & \\
Clients' satisfaction with quality & $\mathrm{N}$ & 88 & 88 & 90 & 91 \\
& $\mathrm{R}$ & 0.146 & 0.092 & 0.213 & 0.180 \\
& $\mathrm{p}$-value & 0.176 & 0.392 & 0.044 & 0.088 \\
Project cost-overrun & $\mathrm{N}$ & 61 & 63 & 64 & 64 \\
& $\mathrm{R}$ & 0.006 & 0.311 & -0.223 & 0.076 \\
& $\mathrm{p}$-value & 0.961 & 0.013 & 0.076 & 0.552 \\
Project time-overrun & $\mathrm{N}$ & 65 & 66 & 67 & 68 \\
& $\mathrm{R}$ & -0.292 & -0.010 & -0.154 & -0.159 \\
& $\mathrm{p}$-value & 0.018 & 0.937 & 0.213 & 0.195 \\
\% time-overrun/initial contr. & $\mathrm{N}$ & 68 & 69 & 70 & 71 \\
period & $\mathrm{R}$ & -0.207 & 0.009 & -0.100 & -0.131 \\
& $\mathrm{p}$-value & 0.090 & 0.942 & 0.412 & 0.277 \\
\% cost-overrun/initial contr. sum & $\mathrm{N}$ & 57 & 58 & & \\
& $\mathrm{R}$ & 0.015 & 0.345 & -0.151 & 0.116 \\
& $\mathrm{p}$-value & 0.913 & 0.008 & 0.258 & 0.386 \\
\hline N=Number & & & & & \\
R=Coefficient of correlation & & & & &
\end{tabular}

Table 7: Results of the Spearman test of correlation between the level of project planning and performance of projects procured by private clients

\begin{tabular}{|c|c|c|c|c|c|}
\hline \multicolumn{2}{|l|}{ Parameter } & Conception & Design & Contract & Overall \\
\hline \multirow[t]{3}{*}{ Clients' satisfaction with duration } & $\mathrm{N}$ & 34 & 36 & 36 & 36 \\
\hline & $\mathrm{R}$ & 0.218 & -0.033 & -0.141 & 0.193 \\
\hline & $p$-value & 0.215 & 0.847 & 0.411 & 0.259 \\
\hline \multirow[t]{3}{*}{ Clients' satisfaction with cost } & $\mathrm{N}$ & 35 & 37 & 37 & 37 \\
\hline & $\mathrm{R}$ & -0.003 & 0.257 & 0.465 & 0.457 \\
\hline & $p$-value & 0.986 & 0.124 & 0.004 & 0.004 \\
\hline \multirow[t]{3}{*}{ Clients' satisfaction with quality } & $\mathrm{N}$ & 35 & 37 & 37 & 37 \\
\hline & $\mathrm{R}$ & 0.202 & -0.140 & 0.148 & 0.216 \\
\hline & $p$-value & 0.244 & 0.407 & 0.382 & 0.200 \\
\hline \multirow[t]{3}{*}{ Project time-overrun } & $\mathrm{N}$ & 20 & 21 & 22 & 22 \\
\hline & $\mathrm{R}$ & 0.711 & 0.643 & 0.106 & 0.248 \\
\hline & $p$-value & 0.001 & 0.002 & 0.637 & 0.265 \\
\hline \multirow[t]{3}{*}{ Project cost-overrun } & $\mathrm{N}$ & 20 & 21 & 22 & 22 \\
\hline & $\mathrm{R}$ & 0.528 & 0.061 & -0.115 & -0.008 \\
\hline & $p$-value & 0.017 & 0.794 & 0.611 & 0.971 \\
\hline \multirow{3}{*}{$\begin{array}{l}\% \text { time-overrun/initial contr. } \\
\text { period }\end{array}$} & $\mathrm{N}$ & 21 & 22 & 23 & 23 \\
\hline & $\mathrm{R}$ & -0.575 & 0.166 & -0.248 & -0.003 \\
\hline & p-value & 0.006 & 0.461 & 0.254 & 0.990 \\
\hline \multirow[t]{3}{*}{$\%$ cost-overrun/initial contr. sum } & $\mathrm{N}$ & 18 & 19 & 20 & 20 \\
\hline & $\mathrm{R}$ & 0.491 & 0.030 & -0.033 & 0.020 \\
\hline & $\mathrm{p}$-value & 0.039 & 0.903 & 0.890 & 0.934 \\
\hline
\end{tabular}

the level of planning at the design stage of project delivery by private clients has significant influence on the amount of delay in the projects but it does not influence client satisfaction and the final cost of projects.

The $p$-value for the test of correlation between the level of contract planning and clients' satisfaction with project cost (0.004) is less than the critical p-value (0.05). Therefore, the hypothesis is rejected. However, the p-values for the test of correlation between the level of contract planning and clients' satisfaction with project duration (0.411) and quality (0.382) and project time-overrun (0.637), cost-overrun (0.611), percentage of time-overrun to initial contract period $(0.254)$ and percentage of cost-overrun to initial contract sum $(0.890)$ are greater than the critical $p$-value 
(0.05). Therefore, the hypothesis is accepted. These results imply that the level of planning at the contract stage of project delivery by private clients has significant influence on their level of satisfaction with project cost but it does not influence their satisfaction with project duration and quality as well as the final time and cost of their projects.

The $p$-value for the test of correlation between the level of overall project planning and clients' satisfaction with project cost $(0.004)$ is less than the critical p-value $(0.05)$ therefore, the hypothesis is rejected. However, the p-values for the test of correlation between the level of overall project planning and clients' satisfaction with project duration $(0.259)$ and quality $(0.200)$ and project timeoverrun (0.265), cost-overrun (0.971), percentage of time-overrun to initial contract period $(0.990)$ and percentage of cost-overrun to initial contract sum (0.934) are greater than the critical p-value $(0.05)$ therefore, the hypothesis is accepted. These results imply that the level of overall project planning done by private clients during construction project delivery has significant influence on clients' level of satisfaction with project cost but it does not influence their satisfaction with project duration and quality as well as the final time and cost of their projects.

\section{DISCUSSION}

The results of the study on the levels of use of selected project conception plans show that the levels of use of project briefs and feasibility and viability studies by both public and private clients are high, while that of life-cycle charts is low. However, public clients use project briefs more than private clients while the latter use feasibility and viability studies and life-cycle charts more than the former. The results tend to indicate that the two categories of clients give more concern and commit more resources to the conceptualisation and definition of project requirements than the definition and scheduling of project delivery time. These results tend to imply that the two clients do not show enough concern for the planning of the delivery time of their projects at conception.

The results of the levels of use of selected project design plans show that public clients use project bill of quantities and specifications more than project drawings while private clients use project drawings more than project bill of quantities and specifications. The differences in the levels of use of the six selected project design plans by the two categories of clients translate into higher level of project design planning by private clients than public clients. The results tend to indicate that public clients are more concerned with the specification of the scope and quality of work than the specification of the project requirements. Private clients on the other hand are more concerned with the documentation of project requirements than the scope and quality of work. Perhaps, this may be as a result of the lower level of use of project brief at project inception stage by private clients.

The results of the levels of use of the five selected contract plans show that both public and private clients give more priority to programme of work than resource schedules (material, labour and plant schedules and cash-flow charts). The major differences in the levels of use of contract plans between the two categories of clients are that private clients give more priority to cash-flow charts than public clients while the latter gives more priority to the use of the remaining four contract plans than the former. These differences translate into higher level of contract planning by public clients than private clients. The higher level of use of cashflow charts by private clients tends to imply that private clients give more priority to the funding of their projects than public clients. This is likely to bring about better planning of the funding of private sector projects than public sector ones.
The results of project stage and overall planning by the two clients have shown that the levels of project conception and overall planning by the two clients are significantly the same, however private clients do more of project design planning than public clients while the latter does more of contract planning than the former. Since the end results of project planning are manifested in project performance, the differences in the planning efforts of the two categories of clients are expected to be reflected in the performances of their projects. The better performance in percentage of time-overrun to initial contract period in projects procured by public clients over those of private clients can therefore be regarded as the results of the higher level of contract planning by public clients. However, the results of the test of difference in the percentage of time-overrun to initial contract period between the two categories of projects have revealed that the difference is insignificant. This result implies that the impact of preparing more contract plans in projects procured by public clients is insignificant.

In the same vein, the better performance in time and costoverruns and percentage of cost-overrun to initial contract sum in projects procured by private clients over those of public clients can equally be regarded as the results of higher levels of project design planning by private clients than public clients. The results of the test of difference in these project performance parameters between the two categories of projects also revealed that the differences are insignificant. The results also imply that the impact of preparing more project design plans in projects procured by public clients is insignificant as far as time and cost overruns are concerned. However, private clients are more satisfied with the duration, cost and quality of their projects than public clients. The results confirm that only the difference in client satisfaction with project duration and cost are significant. These results thus indicate that the impact of the higher level of design planning done in projects procured by private clients is manifested in greater satisfaction of private clients with the delivery time and cost of their projects.

The evaluation of the influence of the level of project stage planning by the two categories of clients shows that the level of project conception planning by public clients has influence on client satisfaction with project duration and time-overrun while that of private clients has influence on project time-overrun, costoverrun and percentage of time-overrun to initial contract period. The results suggest three things. Firstly, increased level of project conception planning can bring about increased performance in delivery time of projects procured by public clients and increased performance of both delivery time and cost of projects procured by private clients. Secondly, although the levels of project conception planning by the two categories of clients are not significantly different, that of private clients has more influence than that of public clients. Thirdly, that increased level of project conception planning by the two clients can influence the delivery time and cost of their projects.

The results showed that the level of project design planning by public clients has influence on project cost-overrun and percentage of cost-overrun to initial contract sum, while that of private clients has influence on only project time-overrun. The results indicate that the higher level of use of project bill of quantities and specifications by public clients has influence on project delivery cost while the higher level of use of project drawings by private clients has influence on project delivery time. What can be deduced from the results is that increased level of use of bill of quantities and specification may reduce budget overrun on projects, while increased level of use of project drawings is likely to reduce delays on projects. This deduction does not consider numerous factors that have an equal influence 
on the delivery time and cost of projects. Another important result of the correlation between the level of use of project design planning and project performance is that project design planning by both public and private clients has no influence on the three selected subjective project performance indicators. That is to say that it does not have any influence on clients' perception of the performance of projects they procure. The implication of this result is that clients may not encourage higher level of project design planning on their own since it does not influence their perception of the performance of projects. Any effort to increase the level of project design planning by the two categories of clients will have to originate from either the project leader or members of the project team because clients' perception of project performance may be quite different from objective measurement. Clients at times may not mind high project cost and time-overruns if the value of such cost and time will give him more satisfaction.

The results also revealed that the level of contract planning by public clients influences client satisfaction with project quality, while that of private clients influences client satisfaction with project cost. These results tend to indicate that the efforts of public clients relative to contract planning are directed at ensuring that they are satisfied with the quality of work while that of private clients is directed at ensuring that they are satisfied with the cost of projects. Increase in the level of contract planning by public clients will tend to increase their level of satisfaction with the quality of work in their projects while increase in the level of contract planning by private clients will increase their level of satisfaction with the cost of their projects. Unlike project design planning, contract planning does not influence any of the four selected objective parameters of project performance. The implication of this result is that the level of contract planning may not influence the actual duration and cost of projects.

The level of overall project planning by public clients has no influence on both subjective and objective indicators of project performance while that of private clients influence only their satisfaction with project cost. This result tends to indicate that there are more important factors than overall level of project planning that influences the performance of projects. Since project stage planning is a component of overall project planning, and it influences project performance, the result thus encourages clients to concentrate on increasing the level of project stage planning in their efforts to improve project performance.

\section{CONCLUSION}

Planning is no doubt one of the functions of management. It is the process that initiates the commencement of management process and is therefore a prerequisite to other management functions such as monitoring, evaluation and control. This study has revealed that in the delivery of construction projects, private clients commit more resources and efforts to project planning at the design stage than public clients. The results tend to imply that private clients manage projects better than public clients at the preconstruction stage. Better management at the conception stage is expected to bring about better results. This is confirmed by a higher level of client satisfaction with project time, cost and quality and lower project time and cost-overruns on the part of private sector projects. This result is a challenge to government and their agencies in Nigeria to show more concern and commit more resources and efforts to project planning at the preconstruction stage of their projects.

The study also revealed that the level of use of project life-cycle charts by the two clients is low. The plan is the tool for effective management of project delivery time and its neglect would mean poor management of project time. This is reflected in the high percentages of time-overrun to initial contract period recorded in the study. Public and private clients in Nigeria need to commit more resources and efforts to the planning of project delivery period in order to improve the performance of their projects.

The level of project stage planning does not influence many of the parameters of project performance. For example, the levels of contract and overall planning have no influence on any of the objective parameters which are the basis of defining project objectives, setting targets and deadlines and monitoring, evaluating and controlling their implementation. The impact of planning on project delivery process and performance is expected to be the same with other management functions. Where project planning is ineffective, the chances of monitoring, evaluation and control being effective may be slim. The result that the level of project planning by Nigerian clients has little influence on project performance should be a matter of concern to all stakeholders. The two categories of clients will need to improve the level of planning of their projects in order to achieve effective monitoring, evaluation and control of their delivery process and improved project performance. There is still room for increased level of use of project conception, design and contract plans on the part of both public and private sector clients in Nigeria.

\section{REFERENCES}

Dvir, D., Raz, T. and Shenhar, J. (2003) 'An empirical analysis of the relationship between project planning and project success', International Journal of Project Management, 21(2), 1-7.

Faniran, O.O., Oluwoye, J.O. and Lenard, D. (1994) 'Effective construction planning', Construction Management and Economics, 12(6), 485-499.

Faniran, O.O., Oluwoye, J.O. and Lenard, D. (1998) 'Interactions between construction planning and influence factors', Journal of Construction Engineering and Management, 124(4), 245-256.

Federal Government of Nigeria (2009) Appropriation acts of the Federal Republic of Nigeria from 2000-2008, Lagos: Federal Government Press.

Hatush, Z. and Skitmore, M. (1997) 'Evaluating contractor prequalification data: selection criteria and project success factors', Construction Management and Economics, 15(2), 129147.

Idoro, G.I. (2008) 'Effect of mechanisation on project performance in the Nigerian construction industry', in proceedings of the RICS Construction and Building Research Conference COBRA 2008, Dublin, 4-5 September.

Josephson, P.E. and Lindstrom, J. (2007) 'Measuring performance in construction projects', in proceedings of the CIB World Building Conference on Construction for Development, Cape Town, 14-18 May, 383-394.

Kotler, P. (2000) Administracao de Marketing (10th edition), Prentice Hall Publishers.

Ling, F.Y.Y. (2004) 'Key determinants of performance of DBB projects in Singapore', Building Research and Information, 32(2), 128-139. 
Ling, F.Y.Y. and Chan, S.L. (2002) 'Performance evaluation of alternative project procurement methods', Research brief, Department of Building, National Univeristy of Singapore.

Ling, F.Y.Y., Chan, S.L., Chong, E. and El, P. (2004) 'Predicting performance of design-build and design-bid-build projects', Journal of Construction Engineering and Management, 130(1), 10-20.

Marjolein, C., Janita, A. and Vos, F.J. (2008) 'Investigating the use of the stakeholder notion in project management literature: a meta-analysis', International Journal of Project Management, 26(3), 749-757.

Michell, K., Bowen, P., Cattell, K., Edward, P. and Pearl, R. (2007) 'Stakeholder perceptions of contractor time, cost and quality management on building projects', in proceeding of the CIB World Building Conference on Construction for Development, Cape Town, 14-18 May, 231-240.

Naoum, S.G. (1991) Procurement systems and project performance, Occasional Paper 45, London: Chartered Institute of Building.

Naoum, S., Fong, D. and Walker, G. (2004) 'Critical success factors in project management', in proceedings of International Symposium on Globalization and Construction, Thailand, 17-19 September.

Neto, J.B., Mourao, Y.R., Ferreira de Freitas, A.A. and Aves, T.L. (2007) 'A method to evaluate and manage client requirements in housing projects', in proceedings of the CIB World Building Conference on Construction for Development, Cape Town, 14-18 May, 310-321.

Nubi, T.O. (2001) 'Comparative study of construction industries in Nigeria and Egypt', Construction, 18(1), 18-33.

Okun, B.O. (2009) 'The impact of time-overrun on the final cost of Federal Government projects', Master of Project Management Project thesis, University of Lagos, Nigeria.

Pheng, L.S. and Ting, D.L.L. (1998) 'Factors influencing design development time of commercial properties in Singapore', Facilities, 16(1/2), 40-51.

Pinto J.K. and Slevin, D.P. (1988) 'Project success: definitions and management techniques', Project Management Journal, 19(1), 67-71.

Project Management Institute (2004) Project management body of knowledge (PMBOK), Pennsylvania: The Project Management Institute Inc.

Robinson, H., Anumba, C., Carillo, P. and Al-Ghassani, A. (2005) 'Business performance measurement in construction engineering organisations', Measuring Business Excellence, 9(1), 13-22.

Sommerville, J., Craig, N. and McCarney, M. (2004) 'Document transfer and communication between distinct construction professionals', in proceedings of COBRA 2004 International Construction Research Conference, Leeds, 7-8 September.

Thomas, S.R., Macken, C.L., Chung, T.H. and Kim, I. (2002) Measuring the impact of the delivery system on project performance: design-build and design-bid-build (NIST GCR 02840), Austin: Construction Industry Institute.
Vincent, K.O. and Joel, E.R. (1995) Principles of total quality, London: Kogan Page. 